\title{
Bismuth Subcitrate
}

National Cancer Institute

\section{Source}

National Cancer Institute. Bismuth Subcitrate. NCI Thesaurus. Code C1351.

A mineral compound that is used to treat duodenal and gastric ulcers associated with

Helicobacter pylori. 